\title{
Some Masoretic Notes of Mss. L and Or 4445 Compared with the Spanish Tradition
}

\author{
M. ${ }^{\mathrm{a}}$ Teresa ORTEgA-MONASTERIO \\ CSIC, Madrid
}

The Hebrew Bible team at the Philology Institute in Madrid is now involved in a new task: the publication of the masorah parva and magna of the Ms. 118-Z-42 (M1) which belongs to the University Library in Madrid. This manuscript served as one of the basic texts for the Complutensian Polyglot edited by Ximenez de Cisneros in the 16th Century. A great number of works have been published in order to determine details about the use of this manuscript or others belonging to the Spanish tradition. But the Ms. M1 has always been considered as the best and most used in all these works, particularly because it was used by Cisneros. Ginsburg described it as a "magnificent codex" and affirms that it was "not only used, but arranged and marked out for the guidance of compilers of the Polyglot» ${ }^{1}$.

The manuscript M1 has been carefully studied by my colleague Dr. Fernández Tejero ${ }^{2}$. It consists of 340 folios and contains the whole Hebrew Bible, except Ex 9:33-24:7. It is written in square characters, in a beautiful Sephardic handwriting, and is dated in Toledo in 1280. The text is arranged in three columns with the masorah parva in the outer margins and between the columns and the masorah magna in the upper and lower margins. The

${ }^{1} \mathrm{CH}$. D. GinsBurg, Introduction to the Massoretico-Critical Edition of the Hebrew Bible, with a Prolegomenon by H. M. OrLinsky (New York 1966) p. 775.

${ }^{2}$ E. Fernández Tejero, La tradición textual española de la Biblia Hebrea (Madrid 1976). 
manuscript has four appendices containing masoretic lists, variations between Eastern and Western manuscripts, rubrics from the Diqdûqê ha-Técamîm and several lists of plene or defective words, or with different readings. The parashiyot and the sedarim are indicated by the letters wi or 0 in the margin.

The rich masorah of the manuscript M1 often enlarges the information given by other manuscripts. In the following examples of the book of Exodus we observe that M1 does not share the errors of L. M1 offers the correct masorah in all the cases and, in many of them it gives more details in its MP than Or 4445 or Ben Hayyim. The lemma is the text of Biblia Hebraica Stuttgartensia (BHS). Since some of the discrepancies of L are indicated by Weil in BHS, his information is included ${ }^{3}$. Cairo and Aleppo manuscripts have obviously been excluded because they do not contain Exodus.

\begin{tabular}{|c|c|c|c|c|c|}
\hline Ex 2:12 & בֶחול & & BHS & MP & (sub loco $)$ \\
\hline M1 & MP & ל & Or 4445 & MP & ל \\
\hline $\mathrm{L}$ & MP & ב (error) & Ben Hayyim & MP & ל חס \\
\hline BHS & MP & (sub loco) & Ex 8:15 & \multicolumn{2}{|c|}{ החַרטמִים } \\
\hline Or 4445 & MP & ל & & MP & ב חס יוד \\
\hline Ben Hayyim & MP & ל & & MP & $\mathrm{no}^{4}$ \\
\hline Ex 3:3 & \multicolumn{2}{|c|}{ אסָרָה נָא } & BHS & MP & ב חס י בליש \\
\hline M1 & MP & $\begin{array}{l}\text { no MP, no } \\
\text { circellus }\end{array}$ & & MP & $\begin{array}{l}\text { (contra textum) } \\
\text { ב ב ב }\end{array}$ \\
\hline & $\mathrm{MM}$ & לית כית יה & Ben Hayyim & MP & ב חס \\
\hline L & MP & $\begin{array}{c}\text { חס ואו ה (error) } \\
\text { (error }\end{array}$ & Ex 9:7 & וִיכברד & פתח \\
\hline BHS & MP & ל (sub loco $)$ & L & MP & (error, or it \\
\hline Or 4445 & MP & no & & & בליש refers to \\
\hline Ben Hayyim & MP & ל חס & & & in Isa 66:5) \\
\hline $\operatorname{Ex} 4: 26$ & לַמוֹלת & & $\mathrm{BH}$ & MP & ל \\
\hline M1 & MP & ל וכת כן & & MP & no \\
\hline $\mathrm{L}$ & MP & 7 (error) & Ben Hayyim & MP & ל \\
\hline BHS & MP & ל (sub loco $)$ & Ex 29:21 & וקדש & \\
\hline Or 4445 & MP & ל וכת כן & M1 & $M P$ & ל \\
\hline Ben Hayyim & MP & ל וחס ויו תניין & $\mathrm{L}$ & MP & $T$ (error) \\
\hline Ex 8:12 & לכִנִם & & BHS & MP & $ל$ \\
\hline M1 & MP & ל וחס & Or 444 & MP & no \\
\hline & MP & ב חס & Ben Has & MP & 3 \\
\hline
\end{tabular}

${ }^{3}$ On this matter see D. Mynatr, The sub loco notes in the Torah of Biblia Hebraica Stuttgartensia (s.l. 1994).

${ }^{4}$ But in the other case, Ex 9:11, it writes in MP on ב. 


\begin{tabular}{|c|c|c|c|c|c|}
\hline Ex 30:37 & טרת & & & & \\
\hline M1 & MP & ל & Or 4445 & MP & no \\
\hline $\mathrm{L}$ & MP & $\lambda$ (error) & Ben Hayyim & MP & ל \\
\hline BHS & MP & ל & & & \\
\hline
\end{tabular}

Other examples require by their complexity a more careful analysis:

\begin{tabular}{|c|c|c|c|}
\hline Ex 31:3 & רוח אלהים & & \\
\hline M1 & 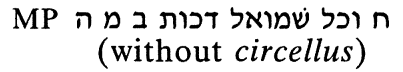 & $\begin{array}{l}\text { BHS } \\
\text { Or } 4445\end{array}$ & $\begin{array}{l}\text { MP } \\
\text { MP }\end{array}$ \\
\hline $\mathrm{L}$ & MP no & Ben Hayyim & MP \\
\hline
\end{tabular}

If we consider the eight cases of the MP, we detect some inconsistences in a few instances. The correct masorah is the MM of M1 given in 2Chron 15:1; it says: eight cases (Gen 1:2, 41:38; Ex 31:3, 35:31; Num 24:2; Ezek 11:24; 2Chron 15:1, 24:20), and the whole book of Samuel except five cases. It means that these five cases present רוח אלהים רוח, not, and they are developed in the MM of M1 in 2Chron 15:1 and in the MM of Or 4445 in Num 24:2. Both Mss. have the same error: they quote 1Sam 19:8 instead of 1Sam 19:9.

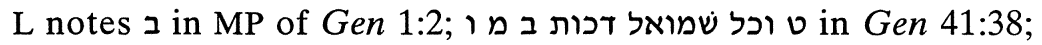

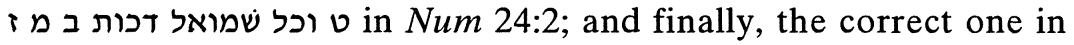
2Chron 15:1: וכל שמואל כות ב מ ה רוח יהוה שות מ ח. In the other four cases it does not write any masorah. Neither in these cases nor in those of Samuel it presents masorah magna.

BHS corrects the masorah of $L$ and notes the correct one ( $n$ (וכל שמואל דכות ב מ ה רוח יהוה 1: in all the cases except Gen and 2Chron 24:20 in which it notes "ח וב בליש וכל שמואל דכות ב מ ה רוח.

Out of the four cases we can collate in Or 4445, the manuscript writes the correct one ( $n$ ) in three of them, and in Num 24:2 it writes 0 in MP but notes $n$ with the simanim in MM.

Finally, Ben Hayyim edition notes $n$ in all the cases except in Ezequiel which has no masorah. The MM is developed in Gen 1:2, 41:38; and Num 24:2. In Samuel, it notes $ה$ in three cases (1Sam 10:6, 19:9; 2Sam 23:2), it has no masorah in 1Sam 16:13 and writes $\lambda$ in 1 Sam 16:14. This is likely because the text is ורוח. In

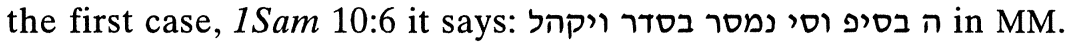

To sum up, all the sources reflect some confusion in the notices, but M1 can be considered as representative of the best 
Tiberian tradition as it reflects the correct masorah in several cases.

$\begin{array}{ll}\text { Ex 1:5 } & \text { i } \\ \text { M1 } & \text { MP, } \\ \text { L } & \text { MP, } \\ \text { BHS } & \text { MP, } \\ \text { Or 4445 } & \text { MP no } \\ \text { Ben Hayyim } & \text { MP, }\end{array}$

If we consider the ten cases given in the MP of L and compare them with the other manuscripts, we observe the following:

1) Or 4445 writes two different notes: ג רוש פסוק in Gen 41:46 and ח וn לש תוספ ט שם אנש in Gen 42:6 and 44:4. It gives the MM in 42:6 with the correct simanim ${ }^{5}$. In Gen 39:1 and 46:4 it does not write any masorah.

2) L writes three different notes: ג ג ראש פסוק in Gen 39:1, 41:46 and 42:6, and gives the MM with the simanim in the second case. It notes, in Gen 44:4, Ex 1:5, Deut 27:12, 2Sam 24:3 and 1Chron 25:2, and writes $ל$ in $P s$ 77:16. The case of Gen 46:4 has no masorah.

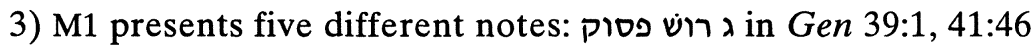
and 42:6, and gives זג מנהון ראש פסוקין וב בלשון תוספת MM of the first one, giving the following simanim: Gen 39:1, 42:6, 41:46, 44:4 and 46:4; Ex 1:5; Ps 77:16; and 2Sam 24:3 and Prov 1:5 for the last two cases. It writes $i$ in Ex 1:5, Gen 44:4 and 46:4. In the case

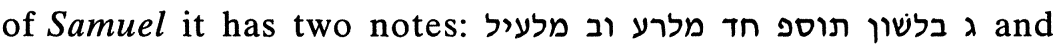
ט שם אנש וחד לשון תוספת. The latter is also repeated in the passage

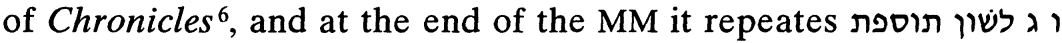
and gives the simanim of Samuel, Prov 1:5 and

\footnotetext{
${ }^{5}$ MM Or 4445 Gen 42:6:

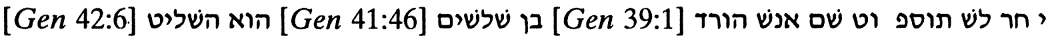

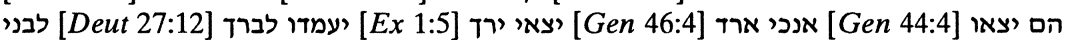
אסף זכור [Ps 77:16] ויאמר [1Chron 25:2] גאלת בזרואב אל המלך [2Sam 24:3].

6 MM M1 1Chron 25:2:

ויוסף ט שום בר נש וסימנהון ויוסף הורד מצרימה [Gen 39:1] ויוסף בן שליט שלים שלים שנה בעמדו לפני

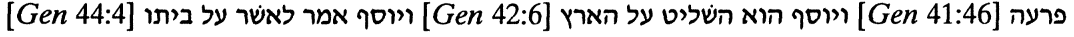

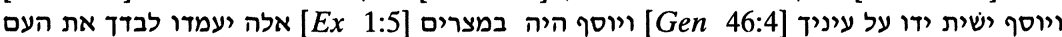

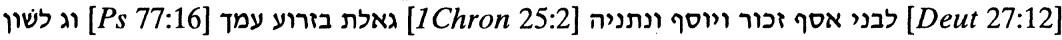

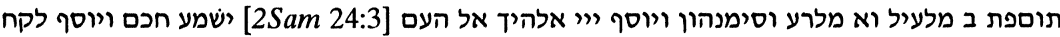

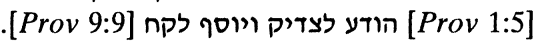


9:9. The masorah three times is unique, it is not recorded in the other manuscripts. Only Frensdorff quotes it in his Masorah magna (p. 85) but here we realize that is not a proper name. This same MM is also given in the passage of Samuel ${ }^{7}$. Finally, the manuscript notes ל וחד יעקב ויוסף in MP of Ps 77:16. The number seven is also recorded in Frensdorff's work, but it refers to seven cases that are plene.

4) Ben Hayyim notes ג ג ר' פ' ט' שום בר נin Gen 39:1 and 41:46. It writes , in Deut 27:12; it has no masorah in Gen 44:4 and 46:4, and Ps 77:16; and notes ל בליש in Samuel and שום בר אנש (46:4 in 1Chron 25:2; and adds ' שום בר נש וסימ in MM. However, it gives the nine simanim and adds: חד בלשון תוספת, which is the case of Samuel.

In spite of the complexity of the masorah of this passage, the manuscript M1 shows the same accuracy than L or Or 4445 . We observe that its coherence is similar to the other manuscripts and to other books of reference as well, but sometimes M1 even offers more detailed notices or gives more than one possibility.

Another particular case is $E x 7: 24$, in the word לשתr:

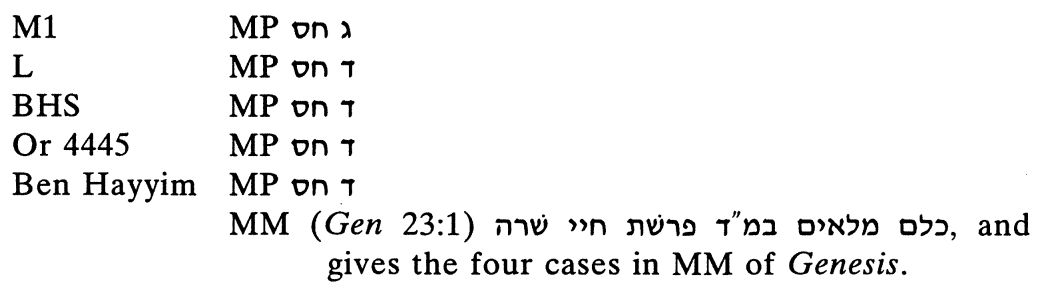

The four cases referred to in L and Ben Hayyim are Ex 7:24, 15:23 and 17:1, and Gen 24:19; but M1 does not contain Ex 9:33 to 24:7, so it is not possible to check the cases of Ex 15:23 and 17:1. The four cases in Or 4445 do not present any variation in relation to L; even in the passage of Gen, M1 says on 7 in MP. לשתת also appears in Ex 7:21 and in M1 is also defective. The

\footnotetext{
7 MM M1 2Sam 24:3:

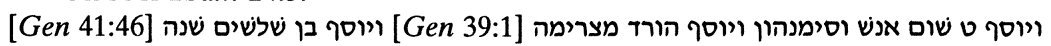
ויוסף הוא השליט על הארץ [Gen 42:6]

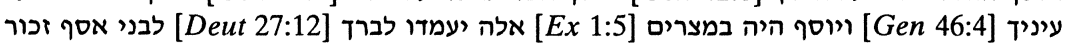

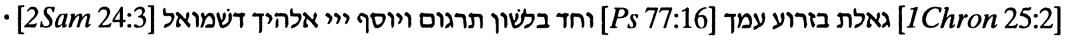

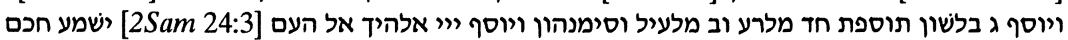

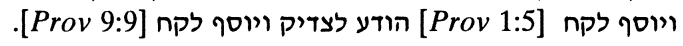


other manuscripts do not record this case. Ben Hayyim notes the four cases in the MM of Gen, with no variants. MP of Ex 7:24 most probably is an error in M1.

In general terms, M1 agrees with those manuscripts best considered; in some cases it gives more specific information and in other cases it shows different notes which are generally soundly based. Only in one case M1 has probably an erroneus masorah, that of Ex 7:24.

In order to widen the scope of the Spanish manuscripts, Or 2201 of the British Library has been also consulted ${ }^{8}$. It is dated in Toledo in 1246 and consists of 368 folios containing the whole Hebrew Bible. Parashiyot and sedarim are indicated and it has a characteristic of very ancient manuscripts, which is the rarely use of the metheg. The masorah parva and magna appear in the margins, as in M1. In spite of being a very good manuscript, and having a very clear masorah, it does not help in the cases under discussion because it has no masorah in any of them.

In contrast to these conclusions, the manuscript $\mathrm{M} 1$ gives further support to the fact that, in Spanish tradition, it represents one of the best codices we have. Contrasting its masorah with the masorah of manuscript M2, which was also used for the composition of Cisnero's Polyglot, could give more evidences on the good quality of Spanish manuscripts.

Although some inconsistences are found in manuscript M1, the good quality of the text and masorah of that codex leads us to classify it as very close to Ben Asher tradition, heading a second class group of manuscripts. It can be considered one of the best codices of the Spanish school, much better than many others taken as good ones in the history of the Biblical tradition.

\footnotetext{
8 It is described in GinsBurg Introduction.
} 


\section{RESUMEN}

Estudio de varias notas masoréticas del libro de Éxodo en el manuscrito M1 (118-Z-42) de la Universidad Complutense de Madrid. Se comparan esas masoras con otras que aparecen en los manuscritos Or 4445 y L, así como en la edición de BHS y Ben Hayyim, con el fin de demostrar la proximidad de la tradición española a la tiberiense y también la gran calidad de los manuscritos españoles.

\section{SUMMARY}

The paper analyzes some masoretic notes of the manuscript 118-Z-42 (M1) of the University of Madrid library in the book of Exodus. The notes of masorah have been compared with those of the manuscripts Or 4445 and L, and with the BHS and Ben Hayyim editions as well, in order to demostrate the proximity of the Spanish codices with the Ben Asher tradition and the high quality of Spanish manuscripts. 